\title{
Article \\ Inhibition of Polyglutamine Misfolding with D-Enantiomeric Peptides Identified by Mirror Image Phage Display Selection
}

\author{
Pauline Elisabeth Kolkwitz ${ }^{1}$, Jeannine Mohrlüder ${ }^{1}$ and Dieter Willbold ${ }^{1,2, * \mathbb{D}}$ \\ 1 Institute of Biological Information Processing (IBI-7), Forschungszentrum Jülich, 52425 Jülich, Germany; \\ p.kolkwitz@fz-juelich.de (P.E.K.); j.mohrlueder@fz-juelich.de (J.M.) \\ 2 Institut für Physikalische Biologie, Heinrich-Heine-Universität Düsseldorf, 40225 Düsseldorf, Germany \\ * Correspondence: d.willbold@fz-juelich.de
}

check for

updates

Citation: Kolkwitz, P.E.; Mohrlüder J.; Willbold, D. Inhibition of Polyglutamine Misfolding with D-Enantiomeric Peptides Identified by Mirror Image Phage Display Selection. Biomolecules 2022, 12, 157. https://doi.org/10.3390/

biom12020157

Academic Editor: Vladimir

N. Uversky

Received: 22 December 2021

Accepted: 12 January 2022

Published: 18 January 2022

Publisher's Note: MDPI stays neutral with regard to jurisdictional claims in published maps and institutional affiliations.

Copyright: () 2022 by the authors. Licensee MDPI, Basel, Switzerland. This article is an open access article distributed under the terms and conditions of the Creative Commons Attribution (CC BY) license (https:// creativecommons.org/licenses/by/ $4.0 /)$.

\begin{abstract}
Nine heritable diseases are known that are caused by unphysiologically elongated polyglutamine tracts in human proteins leading to misfolding, aggregation and neurodegeneration. Current therapeutic strategies include efforts to inhibit the expression of the respective gene coding for the polyglutamine-containing proteins. There are, however, concerns that this may interfere with the physiological function of the respective protein. We aim to stabilize the protein's native conformation by D-enantiomeric peptide ligands to prevent misfolding and aggregation, shift the equilibrium between aggregates and monomers towards monomers and dissolve already existing aggregates into non-toxic and functional monomers. Here, we performed a mirror image phage display selection on the polyglutamine containing a fragment of the androgen receptor. An elongated polyglutamine tract in the androgen receptor causes spinal and bulbar muscular atrophy (SBMA). The selected D-enantiomeric peptides were tested for their ability to inhibit polyglutamine-induced androgen receptor aggregation. We identified D-enantiomeric peptide QF2D-2 (sqsqwstpqGkwshwprrr) as the most promising candidate. It binds to an androgen receptor fragment with 46 consecutive glutamine residues and decelerates its aggregation, even in seeded experiments. Therefore, QF2D-2 may be a promising drug candidate for SBMA treatment or even for all nine heritable polyglutamine diseases, since its aggregation-inhibiting property was shown also for a more general polyglutamine target.
\end{abstract}

Keywords: polyglutamine diseases; protein misfolding diseases; phage display; all-D-peptide therapeutics; protein aggregation

\section{Introduction}

The folding and aggregation of proteins are usually considered to be competing mechanisms [1]. Aggregating proteins are often intrinsically disordered proteins (IDP) [2]. During the aggregation process, monomers of the aggregating protein form small, soluble oligomers which can accumulate into larger aggregates [3]. The most common aggregate structure is the cross-beta amyloid fibril, which has been described at atomic resolution for several examples [4-7].

Aggregates formed by misfolded proteins can lead to cytotoxic effects [8]. Several neurodegenerative diseases are caused by misfolded proteins, such as Alzheimer's disease (AD), Parkinson's disease (PD), prion encephalopathies, amyotrophic lateral sclerosis (ALS) or the heritable polyglutamine diseases, belonging to the triplet repeat diseases [9-11]. Several proteins contain sections with a number of consecutive glutamines, referred to as "polyglutamine proteins" or "polyQ proteins" [12,13]. Polyglutamine proteins form amyloids in a nucleated growth mechanism, with the critical nucleus's size depending on the length of the polyQ chain [14-16]. As observed for other amyloid proteins, the fibrils formed by polyglutamine proteins are able to seed, even between different polyQ lengths $[17,18]$. 
Today, nine heritable polyglutamine misfolding diseases are known, namely Huntington's chorea, spinal and bulbar muscular atrophy (SBMA) or Kennedy's disease, spinocerebellar muscular atrophy 1 (SCA1), SCA2, SCA3 or Machado-Joseph disease, SCA6, SCA7, SCA12, SCA17 and dentatorubral-pallidoluysian atrophy (DRPLA) or Haw River syndrome [19-29]. Still, no effective therapies are known [19]. Analogous to other protein misfolding diseases, the oligomers are thought to be the main toxic species in polyglutamine misfolding diseases [30-32].

Given that the misfolding and aggregation of proteins with an elongated polyglutamine tract is the cause of polyglutamine diseases, inhibiting the aggregation process by stabilizing the native conformation of the polyglutamine protein with a therapeutic agent that binds to natively folded polyglutamine-tracts may be a promising therapeutic approach. Peptides as monomer-stabilizing agents may be suitable as polyglutamine binding partners [33], since they offer a much more effective and specific binding to polyglutamine tracts than small molecules. In one example, a polyglutamine-binding peptide was able to suppress neurodegeneration in Drosophila [34]. Due to the degradation of peptides by metabolic processes [35], it is advantageous to deliver peptides that exclusively consist of amino acid residues in D-enantiomeric conformation (D-peptides). These all-D-peptides exhibit less immunogenity, if at all, and an elevated proteolytic stability compared to their L-enantiomeric counterparts [35,36].

A mirror image phage display selection can be carried out using a D-enantiomeric target. It follows that the D-enantiomeric "mirror image" of the selected peptide ligand can be synthesized and binds to the native L-enantiomeric target $[35,37,38]$. It was already shown that this is a successful approach for neurodegenerative diseases. As an example for an all-D-peptide that progressed into clinical development, the D-enantiomeric peptide RD2 improved the cognition and learning ability in three different mouse models for Alzheimer's disease even by oral administration. It is an example for D-enantiomeric peptides that pass the blood-brain barrier after peripheral administration [39].

In the present study, we aimed to identify a D-enantiomeric peptide ligand of polyglutamine proteins that inhibits their aggregation. To this end, a phage display selection was performed with the mirror image of an androgen receptor fragment containing Q23polyglutamine. A subset of the phage display selected peptides have been synthesized as Denantiomeric peptides and were subsequently tested on the fragment of the L-enantiomeric construct of the androgen receptor with an elongated polyglutamine tract or a universal polyglutamine stretch, with respect to their ability to bind and inhibit their aggregation.

\section{Materials and Methods}

\subsection{Polyglutamine Proteins and Compounds}

The synthetic mirror image of the androgen receptor ARQ23 $3^{51-96}$ was obtained from JPT (JPT Peptide Technologies GmbH, Berlin, Germany) with an N-terminal biotin, connected to the peptide via Trioxatridecan-succinamic acid (ttds)-linker.

The selected all-D-peptide compounds were obtained from Caslo (CASLO ApS, Lyngby, Denmark), whereas L-ARQ46 $6^{51-96}$ and the universal polyglutamine peptide LK2Q46K2 were obtained from peptides \& elephants GmbH (Henningsdorf, Germany). All peptides used in this study are summarized in Table 1. 
Table 1. Synthetic peptides used.

\begin{tabular}{ccc}
\hline Name & Sequence & Synthesized by \\
\hline D-ARQ23 & GasllliqqqqqqqqqqqqqqqqqqqqetsprqqqqqqGedGs & JPT \\
L-ARQ46 & GASLLLLQQQQQQQQQQQQQQQQQQQQQQQ & Peptides \& elephants \\
& QQQQQQQQQQQQQQQQETSPRQQQQQGEDGS & \\
L-K2Q46K2 & KKQQQQQQQQQQQQQQQQQQQQQQQ & Peptides \& elephants \\
QF2D-1 & QQQQQQQQQQQQQQQQQQQQQQQKK & Caslo \\
QF2D-2 & Gnprmteqhqsypphmrrr & Caslo \\
QF2D-3 & sqsqwstpqGkwshwprrr & Caslo \\
QF2D-4 & hnipqklGvwpwpeerrrr & Caslo \\
QF2D-5 & rsfdenswqqflGpGerrr & Caslo \\
QF2D-6 & Gyptypyntqsisswlrrr & Caslo \\
QF2D-7 & sstlmaypnysmqGnerrr & Caslo \\
QF2D-8 & hhwntawdpfhsvrrr & Caslo \\
QF2D-9 & hqrdpswvlyGesrivrrr & Caslo \\
QBP1 & eyeqhwkwpwinnqqhrr & Peptides \& elephants \\
P8 & SNWKWWPGIFD & Caslo \\
\hline
\end{tabular}

\subsection{Disaggregation of Polyglutamine Proteins}

Following the disaggregation protocol that Chen et al. published [40], the polyglutamine proteins were incubated for three days in 1:1 TFA/Hexafluoroisopropanol (HFIP) or overnight in $100 \%$ trifluoroacetic acid (TFA). Afterwards the solvent was evaporated with $\mathrm{N}_{2}$ gas treatment and the polyglutamine protein redissolved in the experiment buffer.

\subsection{Mirror Image Phage Display}

The mirror image phage display was performed with D-Biotin-ttds-ARQ23 as target that was disaggregated in $100 \%$ TFA. The solvent was evaporated by $\mathrm{N}_{2}$ gas treatment. The target was redissolved in Tris-buffered saline (TBS) pH 7.5. Furthermore, D-Biotinttds-ARQ23 was immobilized on a high capacity streptavidin coated polystyrene plate with "SuperBlock" by Thermo scientific (Thermo Fisher scientific, Waltham, MA, USA) for $30 \mathrm{~min}$. TBS pH 7.5 with $0.1 \%$ Tween 20 served as the selection and immobilization buffer. A total of 4 pmol of the target was immobilized on the surface for each selection round. In parallel, Biotin-ttds was immobilized in another well and served as negative control in the empty selection that was performed in parallel to the target selection. The immobilization was followed by blocking with BSA or milk powder $(10 \mathrm{mg} / \mathrm{mL})$ and quenching with biotin for $30 \mathrm{~min}$. Alternating blocking agents were used to avoid selection of BSA or milk powder binders, starting with BSA in the first round. In each selection round $6 \times 10^{11}$ Phages were used as input, starting with the Trico 16 library from Creative Biolabs (Lot: CBLX021820; Creative Biolabs Inc., Shirley, NY, USA). The phages were incubated with the target for $30 \mathrm{~min}$. During the three selection rounds, the number of washing steps was increased from six in selection round 1 to 12 washing steps in the third selection round with TBS pH 7.5 with $0.1 \%$ Tween 20 and $2 \mathrm{mg} / \mathrm{mL}$ BSA as washing buffer. The phages were eluted with $100 \mu \mathrm{L} 0.2 \mathrm{M}$ Glycin- $\mathrm{HCl}(\mathrm{pH} 2.2$ ) that was incubated in the well for $10 \mathrm{~min}$ at room temperature (RT). Consecutively the solution containing the eluted phages was removed from the plate and mixed with $25 \mu \mathrm{L} 1 \mathrm{M}$ tris- $\mathrm{HCl} \mathrm{pH} \mathrm{9.1.} \mathrm{Of} \mathrm{this} \mathrm{neutralized}$ phage containing solution (output), $110 \mu \mathrm{L}$ were added to a $20 \mathrm{~mL}$ Escherichia coli $\mathrm{K} 12$ ER2738 culture that were grown in lysogeny broth (LB)-medium with $20 \mu \mathrm{L}$ Tetracyclin to an $\mathrm{OD}_{600}$ of 0.1. $5 \mu \mathrm{L}$ of the output were mixed with $95 \mu \mathrm{L} \mathrm{LB}$ medium and a dilution series from $10^{-2}$ to $10^{-8}$ was prepared with LB medium. $100 \mu \mathrm{L}$ E. coli K12 E2738 were added to each well and the resulting $200 \mu \mathrm{L}$ were plated with $800 \mu \mathrm{L}$ of top agar (10 g Bacto-Trypton, $5 \mathrm{~g}$ yeast extract, $5 \mathrm{~g} \mathrm{NaCl}, 1 \mathrm{~g} \mathrm{MgCl}, 7 \mathrm{~g}$ agarose, $11 \mathrm{H}_{2} \mathrm{O}$ ) on $35 \times 10 \mathrm{~mm}$ plates (Sarstedt, Nümbrecht, Germany) with IPTG-xGal agar $(1 \mu \mathrm{L} / \mathrm{mL}$ stock solution containing $1.25 \mathrm{~g}$ IPTG, $1 \mathrm{~g} \mathrm{X}$-gal and $25 \mathrm{~mL}$ DMSO). The plaques were counted after an overnight incubation at $37^{\circ} \mathrm{C}$. 
After $4 \mathrm{~h}$ incubation, the $20 \mathrm{~mL}$ E. coli ER2738 culture was centrifuged for $20 \mathrm{~min}$ at $2700 \mathrm{~g}, 4^{\circ} \mathrm{C}$. The supernatant was mixed with $7 \mathrm{~mL}$ PEG8000- $2.5 \mathrm{M} \mathrm{NaCl}$ to precipitate the phages and incubated overnight on ice. After a second incubation at $2700 \mathrm{~g}, 4^{\circ} \mathrm{C}$ for $60 \mathrm{~min}$, the phage containing pellet was redissolved in $1 \mathrm{~mL}$ TBS that were centrifuged for $5 \mathrm{~min}$ at $10,600 \mathrm{~g}$. The supernatant was mixed with $200 \mu \mathrm{L}$ PEG-NaCl and incubated on ice for $1 \mathrm{~h}$ to precipitate the phages. The precipitation was centrifuged for $45 \mathrm{~min}$ at $2600 \mathrm{~g}$, the pellet was resuspended in $100 \mu \mathrm{L}$ TBS (input). The input's phage concentration was determined by spectrophotometry [41] in TBS using a 1:10 dilution. This procedure was repeated for all selection rounds. In selection round two and three, the respective input was also added to a well prepared in a similar fashion to the empty selection well and served as a direct control.

The single-stranded phage DNA was prepared for analysis by next generation sequencing (NGS) as described previously [42].

The data evaluation was performed with the software Target Sequencing Analysis Tool (TSAT) and Hammock [43], as described previously [42].

\subsection{SPR Measurements}

Binding studies were performed with surface plasmon resonance (SPR) in a Biacore T200 device (Biacore, GE Healthcare, Uppsala, Sweden). The L-ARQ46 was immobilized on a CM5 Chip via amine coupling (1400 RU). The selected D-enantiomeric peptide compound QF2D-2 was dissolved in the running buffer (TBS pH 7.5 with $0.05 \%$ Tween) and served as the analyte in multi-cycle experiments, with the highest peptide concentration being $20 \mu \mathrm{M}$. Experiments were performed at $25^{\circ} \mathrm{C}$ with a flow rate of $45 \mu \mathrm{L} / \mathrm{min}$. After a contact time of $110 \mathrm{~s}$ and a dissociation time of $400 \mathrm{~s}$, the surface was regenerated with low $\mathrm{pH}$ (Glycin-HCl, pH 2.2) for $30 \mathrm{~s}$ with a flow rate of $30 \mu \mathrm{L} / \mathrm{min}$. The data were evaluated via affinity fit of the steady state using the biacore evaluation software.

Additionally, K2Q46K2 was immobilized on a polycarboxylate-chip with $200 \mathrm{~nm}$ matrix (530 RU). The selected D-enantiomeric peptide compound QF2D-2 was dissolved in running buffer (TBS pH 7.5 with $0.05 \%$ Tween) and served as analyte in multi-cycle experiments. Experiments were performed at $25{ }^{\circ} \mathrm{C}$ with a flow rate of $20 \mu \mathrm{L} / \mathrm{min}$. After a contact time of $140 \mathrm{~s}$ and a dissociation time of $400 \mathrm{~s}$. The data were evaluated via affinity fit of the steady state using the biacore evaluation software.

\subsection{Thioflavin T Assays}

Thioflavin T (ThT) assays were performed to monitor the time-dependent formation of amyloidogenic aggregates. The assays were performed at $37^{\circ} \mathrm{C}$ in TBS pH $7.5(15 \mu \mathrm{M}$ ThT) with $300 \mathrm{rpm}$ double orbital shaking. All buffers were sterile filtrated beforehand. Polyglutamine proteins were disaggregated as described before. The peptides were prediluted in TBS $\mathrm{pH}$ 7.5. The disaggregated polyglutamine protein in buffer was mixed with $15 \mu \mathrm{M}$ ThT and the pre-diluted peptides in a 96-well half-area flat-bottom microplate (Corning, New York, NY, USA). During the experiment all wells contained $100 \mu \mathrm{L}$ ThT solution. Sealing the plate with foil (Thermo Fisher Scientific, Waltham, MA, USA) helped to prevent evaporation. The progression of fluorescence intensity was tracked by a microplate reader (BMG Labtech, Ortenberg, Germany).

The lag-time was estimated as follows: the average variation of the curve was determined with the last ten values of the steady state. Since the signal usually dropped at the beginning of the measurement, those values were not considered as starting point. As soon as the steady signal at the beginning exceeded the average variation, the lag-time was considered to be over.

For seeded experiments, the slope of the curve was considered instead of the lag-time because seeding eliminated the lag-time. The slope was determined by plotting the first values and fitting with a linear fit. The considered period ( 2 to $3.5 \mathrm{~h}$ ) was similar for the curves compared with. 


\subsection{Production of Soluble Aggregate Fragments}

The disaggregated ARQ46 was diluted to $300 \mu \mathrm{M}$ and incubated at $37^{\circ} \mathrm{C}, 400 \mathrm{rpm}$. After $24 \mathrm{~h}$ large, white aggregates were visible in the tube. The sample was sonicated (Sonopuls, Bandelin electronic GmbH \& Co. KG, Berlin, Germany) four times for $15 \mathrm{~s}$ with an amplitude of $60 \%$. Between the sonification steps the sample was cooled on ice. Post sonification the sample was turbid. It was centrifuged at $100,000 \mathrm{~g}$ for $1 \mathrm{~h}$ at $4{ }^{\circ} \mathrm{C}$ to remove insoluble aggregates from the solution. The clear supernatant was used for seeding with soluble aggregate fragments.

\subsection{Spectroscopy}

After disaggregation, polyglutamine proteins were dissolved in TBS $\mathrm{pH} 7.5$ and measured in a quartz crystal cuvette with $1 \mathrm{~mm}$ light path (Hellma Analytics, Müllheim, Germany) in a CD spectrometer (J-1100, Jasco Deutschland GmbH, Pfungstadt, Germany) with 4 acquisitions. The High tension voltage (HT) was monitored throughout the experiment. Data for which the HT exceeded $600 \mathrm{~V}$ were excluded. Buffer measurements served as references. Analogous, samples containing $50 \mu \mathrm{M}$ ARQ46 and $50 \mu \mathrm{M}$ QF2D-1 or QF2D-2 were measured and referenced with the measurement of $50 \mu \mathrm{M}$ QF2D-1 or QF2D-2 alone. Subsequently, the ARQ46 alone and with QF2D-1 or QF2D-2 were aggregated at $37^{\circ} \mathrm{C}$ and $400 \mathrm{rpm}$ for 7 days. The CD spectra of the samples were monitored after $24 \mathrm{~h}, 48 \mathrm{~h}$ and $168 \mathrm{~h}$ of aggregation.

\section{Results}

\subsection{Aggregation and Disaggregation of Polyglutamine Proteins}

In this study we followed a novel approach to identify therapeutics for protein misfolding diseases by stabilizing the protein's native conformation with all-D-enantiomeric peptides as ligands. To this end it is essential to find binding partners of the monomeric target proteins.

It is well known that polyglutamine proteins aggregate spontaneously when the number of glutamines exceeds a certain threshold [16]. This was observed for the tested constructs L-K2Q46K2 and L-ARQ46. Because of their spontaneous aggregation behavior, it was necessary to ensure that experiments were performed with monomeric polyglutamine proteins, whenever requested. The published disaggregation protocol [40] was adapted for the investigated polyglutamine proteins. Circular dichroism (CD) experiments with the disaggregated samples showed a mixture of random coil and alpha-helical structure (Figure 1A, grey curve). This is consistent with published CD-experiments [18]. After incubation at $37^{\circ} \mathrm{C}$, the $\mathrm{CD}$ measurement showed $100 \%$ beta-sheet structure (Figure $1 \mathrm{~A}$, black curve). It follows that the disaggregation protocol is successful and the protein was in its native conformation and capable of spontaneous misfolding after the disaggregation procedure.

This is supported by the Thioflavin T (ThT) aggregation assays, which showed that ARQ46 and K2Q46K2 (practically identical behavior, data not shown) spontaneously formed amyloid fibrils after few hours lag time, when incubated in TBS pH 7.5 at $37^{\circ} \mathrm{C}$ (Figure 1B). The length of the lag time was dependent on the polyglutamine peptide's concentration. It was observed that there was a longer and more reproducible lag-time in aggregation assays when ARQ46 was disaggregated in 1:1 TFA/HFIP. Lower concentrations of the ARQ46 then $\mathrm{K} 2 \mathrm{Q} 46 \mathrm{~K} 2$ were required for similar aggregation results considering the lag time, which was eliminated by adding $5 \%$ seeds monomer equivalent. 
A

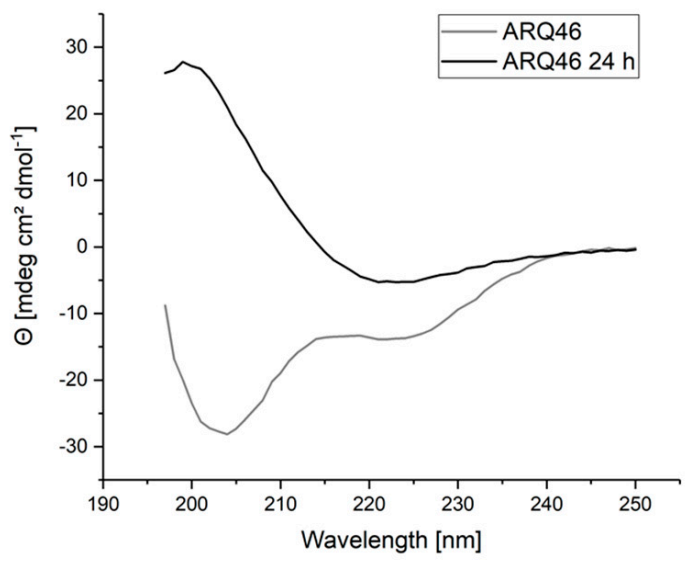

B

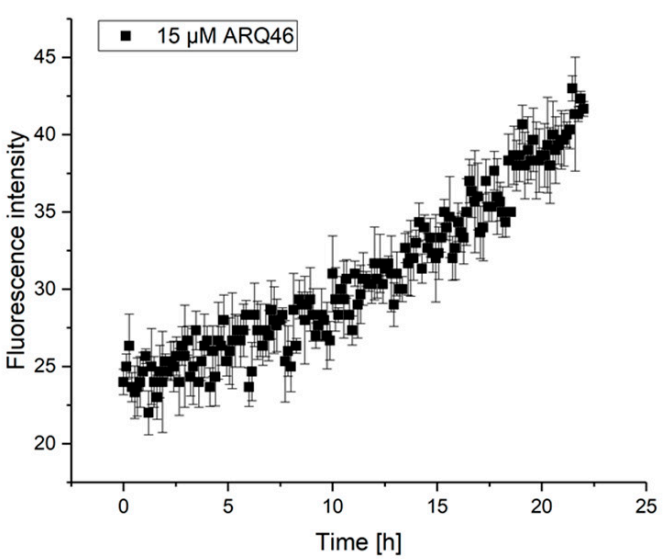

Figure 1. Disaggregation of ARQ46; Examination of ARQ46 post disaggregation. (A) CDmeasurement of freshly disaggregated (100\% TFA) ARQ46 (grey) in TBS pH 7.5 or the same sample incubated at $37^{\circ} \mathrm{C}$ with $400 \mathrm{rpm}$ shaking for $24 \mathrm{~h}$ (black). (B) ThT-Measurement of $15 \mu \mathrm{M}$ ARQ46, disaggregated with 1:1 TFA/HFIP, in TBS pH 7.5 measured at $37^{\circ} \mathrm{C}$.

\subsection{Mirror Image Phage Display Selection}

\subsubsection{Target Preparation}

A mirror image phage display selection was performed to identify peptide ligands of polyglutamine proteins. To this end, a D-enantiomeric fragment of the androgen receptor comprised of amino acid residues 51 to 96 with a polyglutamine tract of 23 glutamines (D-ARQ23) was presented as target during the three selection rounds. An N-terminal biotin tag was connected via a ttds-linker to the D-ARQ23. Following the disaggregation protocol, with 100\% TFA, the D-ARQ23 was disaggregated prior to the selection in order to assure its monomeric conformation. The disaggregation's success was verified via CD spectroscopy. The CD sample was stored analogous to the target samples and measured after the selection's completion to ensure the target stayed disaggregated for the selections time period. The resulting CD spectrum was opposite to the curve typical for disaggregated polyglutamine proteins (Figure 2), exactly as expected for a D-enantiomeric peptide.

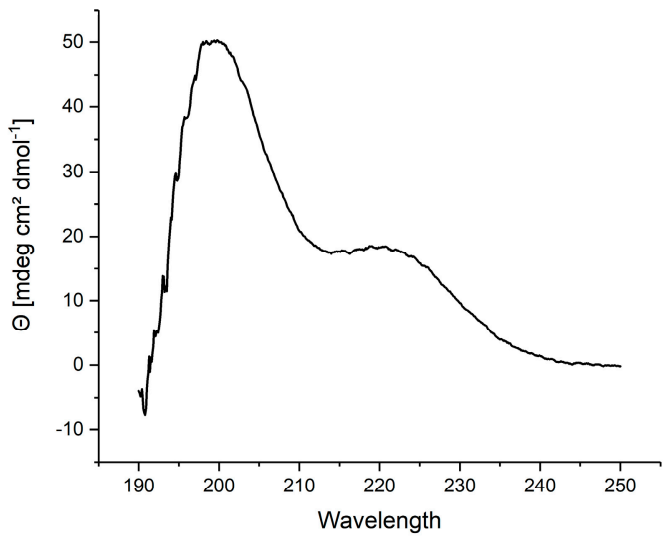

Figure 2. CD-spectrum of D-ARQ23 disaggregated with $100 \%$ TFA; Prior to the phage display selection D-ARQ23 was disaggregated with TFA to ensure selection on monomeric target. CDspectrum was recorded in $10 \mathrm{mM}$ Tris $\mathrm{pH} 8$.

\subsubsection{Selection and Evaluation}

The selected phages from the phage library presenting 16mer peptides on their surface were analyzed via Next Generation Sequencing (NGS). The sequencing data were evaluated via TSAT, evaluation software developed by our work group [42] and the clustering tool 
Hammock [43]. There was no general sequence alignment of all selected sequences possible. The sequences were ranked by their empty score, which is the ratio between the frequency of the respective sequence in the target selection and the empty selection. To ensure comparability, the frequency was normalized to parts per million, because NGS runs might have different read numbers.

In case the sequence is not present in the empty selection at all, half of the minimal empty value was used to calculate the empty score. The 50 sequences with the highest empty scores were compared regarding other parameters (Figure 3). One of those parameters is the enrichment factor, which is the ratio between the frequency in target selection round 3 and the frequency in the original library. If the sequence's frequency in the library was zero, the half-minimal value was used, as described for the empty score. The ratio of target selection and direct control was also taken into account. It gives good hints concerning the phage's target specificity, since the same input is presented to target or control well. If a sequence is more frequent in the target selection than the direct control it is highly probable that this sequence is a specific target binder. The last considered parameter was the formation of clusters, respectively sequences that are similar to each other. The Hammock tool was used to search the sequences for clusters. A cluster including many similar sequences can be used as a hint for target specific sequence enrichment. The selected sequences were also compared with those selected on a universal polyglutamine target, D-K2Q23K2. There were similarities in the preferred amino acid residues and also some sequences identical in both selections, another hint that this set-up is suitable to select specific polyglutamine binders.

A

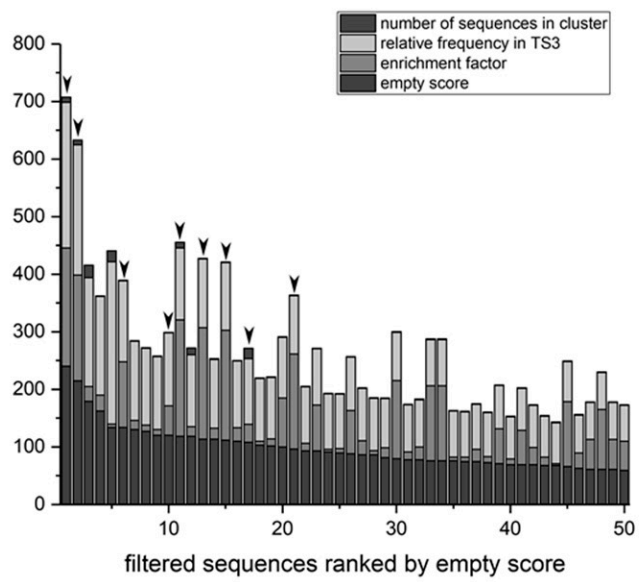

B

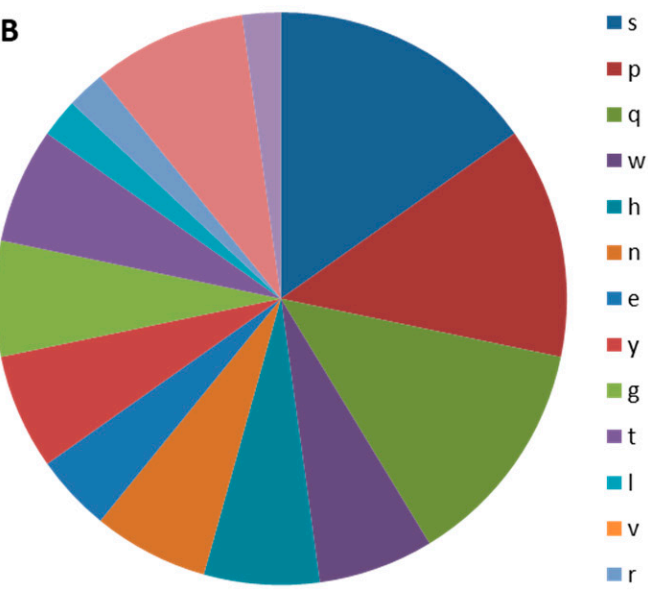

Figure 3. Sequences selected on D-ARQ23 ranked by empty score. (A) The sequences found by NGS sequencing were ranked by their empty score (deep dark grey). The sequences with the 50 highest empty scores are depicted. The enrichment factor (grey), relative frequency in target selection 3 (TS3; light grey) as well as the number of sequences with similar motives in the respective clusters (dark grey) are visualized within the bar chart. Sequences that were further investigated are marked with black arrows. (B) Amino acid residue type abundance in QF2D-1, QF2D-2 and QF2D-6.

Considering the described parameters, nine D-enantiomeric peptide sequences were chosen for further experimental investigations for their ability to inhibit the aggregation of polyglutamine proteins, marked with arrows in Figure 3. The peptides resulting from the marked sequences were named consecutively QF2D-1, QF2D-2 QF2D-3, QF2D-4, QF2D-5, QF2D-6, QF2D-7, QF2D-8 and QF2D-9. The sequences of the peptide and the considered parameters are shown in Table 2. 
Table 2. D-peptides selected on ARQ23 that were further investigated with three additional, Cterminal arginine residues.

\begin{tabular}{|c|c|c|c|c|c|c|}
\hline Peptide Name & Sequence & Empty Score & $\begin{array}{l}\text { Enrichment } \\
\text { Factor }\end{array}$ & $\begin{array}{l}\text { Frequency in } \\
\text { Library }\end{array}$ & $\begin{array}{l}\text { Cluster } \\
\text { Size }\end{array}$ & TS3/DC \\
\hline QF2D-1 & Gnprmteqhqsypphmrrr & 240 & 205 & 1.2 & 9 & 2.7 \\
\hline QF2D-2 & sqsqwstpqGkwshwprrr & 215 & 184 & 1.2 & 8 & 9 \\
\hline QF2D-3 & hnipqklGvwpwpeerrrr & 134 & 114 & 1.2 & 1 & 6.1 \\
\hline QF2D-4 & rsfdenswqqflGpGerrr & 120 & 51 & 2.4 & 1 & 1.7 \\
\hline QF2D-5 & Gyptypyntqsisswlrrr & 118 & 202 & 0 & 10 & 5 \\
\hline QF2D-6 & sstlmaypnysmqGnerrr & 113 & 194 & 0 & 1 & 10.3 \\
\hline QFF2D-7 & hhwntawdpfhsvrrr & 112 & 191 & 0 & 1 & 2 \\
\hline QF2D-8 & hqrdpswvlyGesrivrrr & 108 & 31 & 3.7 & 18 & 1.4 \\
\hline QF2D-9 & eyeqhvkwpwinnqqhrrr & 100 & 85 & 1.2 & 1 & 55.4 \\
\hline
\end{tabular}

Overall, QF2D-1 had the highest empty score and enrichment factor. It was rare in the library and the leading sequence in a cluster with 8 other, similar sequences. It had a TS3/DC3 ratio bigger than 1, meaning it was more frequent in the target selection than in the direct control. The same was true for QF2D-2 that had the second highest empty score and a high enrichment factor. Similar to QF2D-1, it was rare in the library and found to be the leading sequence in a cluster. Compared to the other sequences it had the third highest ratio between Target selection and direct control.

The sequences with the third to fifth highest empty scores were excluded from further investigation, because they were also frequent in the library, meaning their enrichment factor was not as high.

We found that QF2D-3 had the sixth highest empty score and a high enrichment factor, as well as a high TS3/DC3 value, which is why it was tested.

The sequences with the seventh to ninth highest empty scores had low enrichment factors and were not included in any clusters; therefore they were not further investigated.

Additionally, QF2D-4 had the tenth highest empty score and was rare in the library, similar to QF2D-5, which was very rare in the library. QF2D-5 with the 11th highest empty score and had the second highest enrichment factor. It was also leading sequence in a cluster and had a high TS3/DC3 ratio. QF2D-7 was chosen for further investigation for the same reason.

However, QF2D-6 was also picked because of its high enrichment factor and the second highest TS3/DC3 ratio.

Moreover, QF2D-8 was the leading sequence in the cluster including the 18 sequences, whereas QF2D-9 had the highest TS3/DC3 ratio.

All other sequences were excluded, because their empty scores were not considered high enough.

By comparing the amino acid residue composition of the nine investigated peptides with the 50 leading sequences in the empty selection, it becomes apparent that three amino acid residues serine, proline and glutamine increased their proportion. Whereas serine, proline and glutamine make up $23 \%$ of the amino acid residues in the peptides selected in the empty selection, $33 \%$ of the amino acid residues in the nine selected peptides were serine, proline or glutamine. This becomes even more striking when we only consider the three peptides that had an effect in the seeded assay: QF2D-1, QF2D-2 and QF2D-6. 40\% of the residues in these peptides are serine, proline or glutamine (Figure 3B). Their abundance nearly doubled in these peptides compared with the average of the empty selection.

Polyglutamine tracts modulate protein-protein interactions, especially between intrinsically disordered proteins [12]. It is not surprising that a glutamine rich sequence would be a preferred interaction partner for the monomeric polyglutamine target. Proline can interfere with the aggregation of polyglutamine proteins [44]. A proline-rich peptide could be effective in inhibiting the aggregation of polyglutamine proteins. The enrichment of specific residues compared to the empty selection is another hint that there was target-specific 
selection pressure that led to the enrichment of sequences with a high frequency of serine, proline and glutamine.

Three arginine residues were added C-terminally to the peptides that were further investigated to increase the peptide's solubility. Arginines can increase cell membranes permeability [45].

\subsection{Impact on Polyglutamine Aggregation}

In order to screen the selected all D-peptide compounds for their effect on polyglutamine aggregation, QF2D-1, QF2D-2, QF2D-3, QF2D-4, QF2D-5, QF2D-6, QF2D-7, QF2D-8 and QF2D-9 were tested via ThT-assay. The fluorescence intensity of ThT is proportional to amyloid content of the sample. In this first screening with equimolar ratios between peptides and ARQ46, all nine compounds had an inhibitory effect. All of them delayed ARQ46 aggregation and reduced the fluorescence intensity of the steady state (Figure 4). None of the compounds were ThT-active when no polyglutamine protein was present. For QF2D-9 this control was not evaluable, because the well dried during the experiment. Interestingly, all nine compounds reduced the fluorescence intensity of the steady state rather similarly to approx. $70 \%$ of the fluorescence intensity measured for ARQ46. There was higher variety among the compounds with respect to the lag-time elongation. The lag-time elongation varied between 76\% (QF2D-8) and 207\% (QF2D-7).

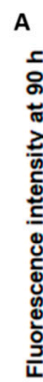

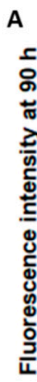

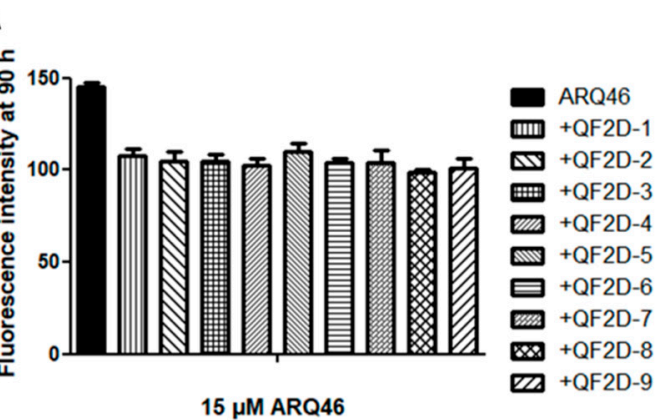

B
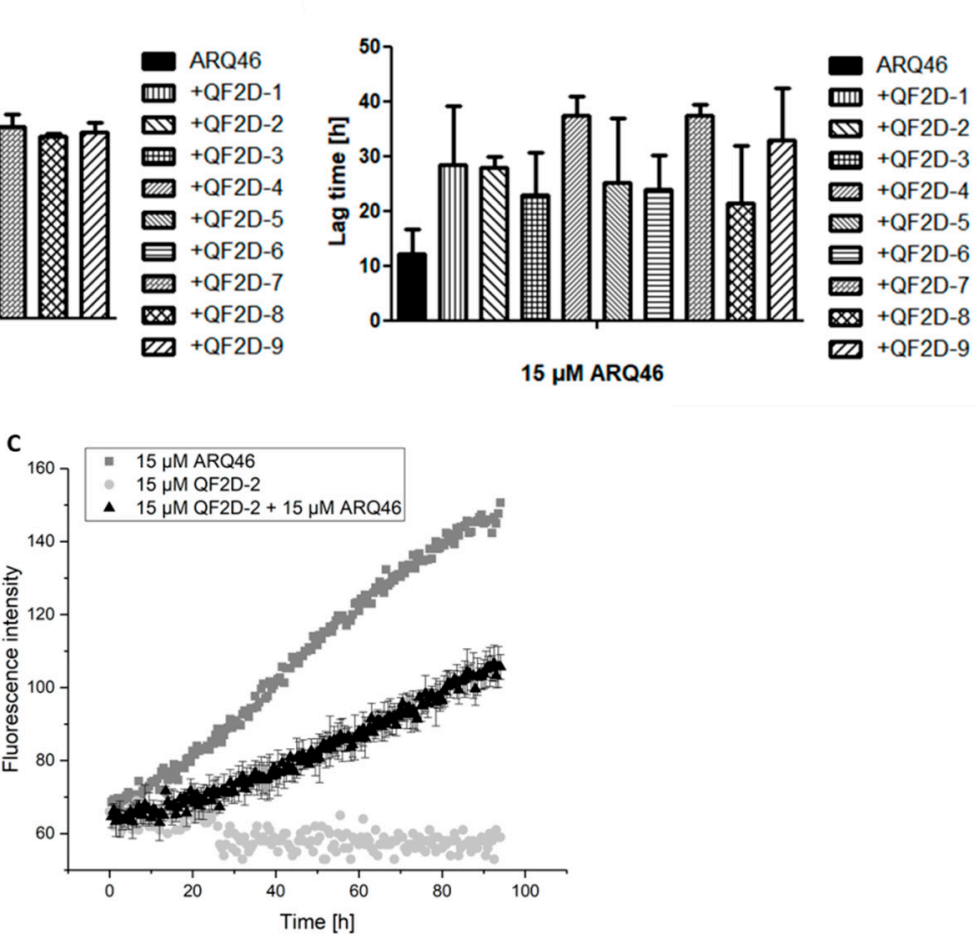

Figure 4. Compounds inhibit the aggregation of ARQ46; ThT assay with L-ARQ46 was performed at $37^{\circ} \mathrm{C}$ in TBS $\mathrm{pH}$ 7.5. The progression of fluorescence intensity was measured every $30 \mathrm{~min}$ at $\lambda \mathrm{ex}=$ $410 \mathrm{~nm}$ and $\lambda \mathrm{em}=482 \mathrm{~nm}$ with $30 \mathrm{~s}$ agitation at $300 \mathrm{rpm}$ before every measurement. (A) Fluorescence intensity measured at $90 \mathrm{~h}$ of the aggregation assay starting with $15 \mu \mathrm{M}$ monomeric ARQ46 without peptide and with $15 \mu \mathrm{M}$ QF2D-1, QF2D-2, QF2D-3, QF2D-4, QF2D-5, QF2D-6, QF2D-7, QF2D-8 or QF2D-9. (B) Lag time estimated from the aggregation assay of $15 \mu \mathrm{M}$ monomeric ARQ46 without peptide and with $15 \mu \mathrm{M}$ QF2D-1, QF2D-2, QF2D-3, QF2D-4, QF2D-5, QF2D-6, QF2D-7, QF2D-8 or QF2D-9. (C) Measurement example of the described ThT-assay with ARQ46 (dark grey) and QF2D-2 (black). QF2D-2 in TBS buffer alone served as a control (light grey). The mean fluorescence intensity is shown for each time point. The experiment was performed in three-fold determination. 
Patients suffering from polyglutamine diseases present with aggregates in their neurons before symptom onset and therefore probably also before treatments start. Thus, a promising drug candidate should inhibit the aggregation in presence of pre-formed aggregates. Since small, soluble oligomers are suspected to be the main toxic species [46], the compounds were tested for their inhibitory effect in presence of soluble polyglutamine aggregate fragments (Figure 5). The effects of the compounds were compared with two controls. The first, P8, has been selected on SOD1 and should not bind to polyglutamine proteins. The second, QBP1, is claimed to inhibit the aggregation of polyglutamine proteins [33].

A

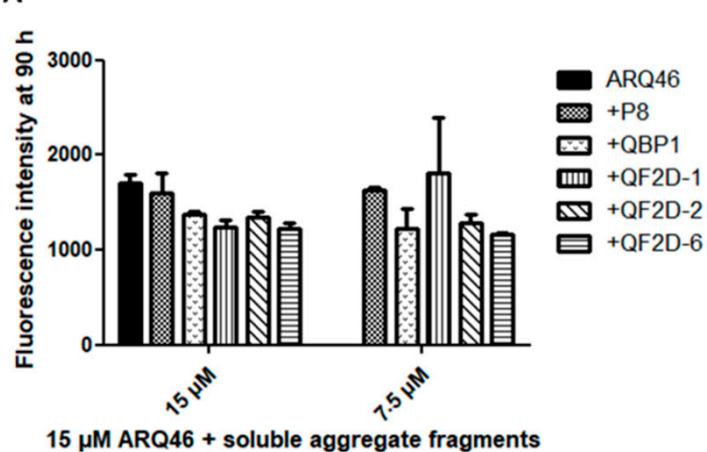

B

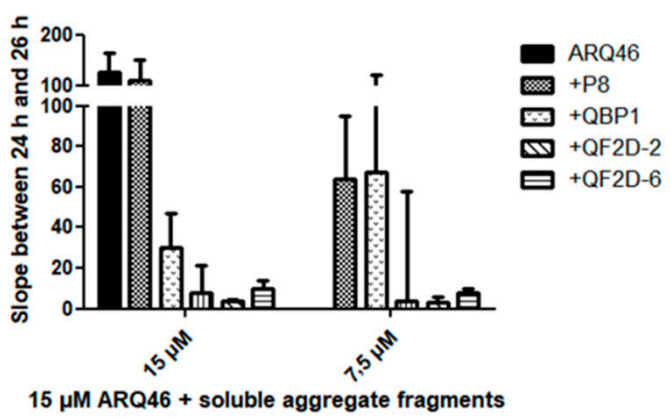

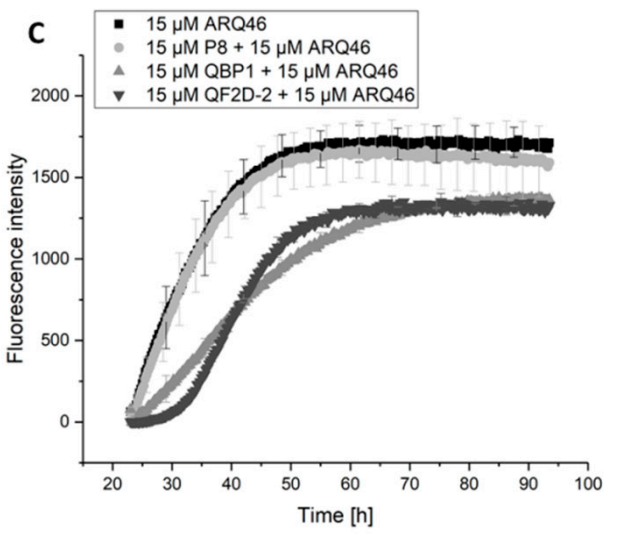

Figure 5. QF2D-1, QF2D-2 and QF2D-6 inhibit the aggregation of ARQ46 in presence of soluble aggregate fragment seeds; ARQ46 was aggregated, and the solution was subject to spinning at $100,000 \mathrm{~g}$ in an ultracentrifuge. The supernatant was preincubated with $15 \mu \mathrm{M}$ and $7.5 \mu \mathrm{M}$ of one of the selected compounds in TBS at $37{ }^{\circ} \mathrm{C}$. After $23 \mathrm{~h}, 15 \mu \mathrm{M}$ monomeric ARQ46 were added, and the fluorescence intensity was measured every $15 \mathrm{~min}$ at $\lambda \mathrm{ex}=448 \mathrm{~nm}$ and $\lambda \mathrm{em}=482 \mathrm{~nm}$ with agitation at $300 \mathrm{rpm}$ between measurements. P8 served as a control compound that was not selected on polyglutamine, whereas QBP1 is claimed to bind polyglutamine tracts and inhibit polyglutamine-driven aggregation. (A) Fluorescence intensity of P8, QBP1, QF2D-1, QF2D-2 and QF2D-6 in equimolar and sub stoichiometric ratio at $90 \mathrm{~h}$. (B) The data points acquired between $24 \mathrm{~h}$ and $26 \mathrm{~h}$ - shortly after monomer addition- were fitted with a linear fit. The slope was compared. (C) Measurement example of the described ThT-assay with ARQ46 (black), P8 (light grey), QBP1 (grey) and QF2D-2 (dark grey). The mean fluorescence intensity is shown for each time point. The experiment was performed in two-fold determination.

In presence of soluble aggregates, there was no lag-phase observable for the sample containing only ARQ46 or ARQ46 and P8. To compare the aggregation onset, the slope of the curve between $24 \mathrm{~h}$ and $26 \mathrm{~h}$, so shortly after monomer addition, was calculated with a linear fit of the curves (Figure 5B). This slope represents the formation rate of amyloid aggregates by the increase of ThT-fluorescence per hour. The curves measured for ARQ46 and P8 were the steepest. QF2D-1, QF2D-2 and QF2D-6 had an aggregation inhibiting effect 
and decreased the slope, even when ARQ46 was present in excess. The effect of QF2D-1, QF2D-2 and QF2D-6 decreased the slope more effectively then QBP1, with QF2D-2 being the most and QF2D-6 being the least effective aggregation inhibiting compound. QF2D-2 reduced the slope by $96 \%$ compared with $\mathrm{P} 8$ and still by $86 \%$ compared to QBP1.

In the presence of soluble aggregate fragments, the effect of QBP1 was considerably smaller than that of the selected peptides. Since it is expected that a patient treated with a therapeutic agent for polyglutamine diseases already has aggregates formed in their neurons, the selected compounds might be more effective than QBP1 in this context.

During the aggregation process, the polyglutamine protein will change its secondary structure to a beta-sheet rich conformation. The selected compounds are expected to decelerate this transition by stabilizing the native conformation of the polyglutamine protein. The transition is monitored by CD spectroscopy. Freshly disaggregated, L-ARQ46 showed negative peaks at $222 \mathrm{~nm}$ and $205 \mathrm{~nm}$, which is similar to the CD spectrum published by Chen et al. [18]. After $24 \mathrm{~h}$ incubation at $37{ }^{\circ} \mathrm{C}$, the spectrum showed a positive peak at $200 \mathrm{~nm}$ range when no peptide was added to the sample. After $48 \mathrm{~h}$ incubation the spectrum showed that the sample was converted to beta-sheet $[47,48]$ with a minimum at $220 \mathrm{~nm}$ and a maximum at $200 \mathrm{~nm}$. (Figure 6A).

The sample containing QF2D-1 and ARQ46 (Figure 6B) did not show peaks in the positive or negative range after $24 \mathrm{~h}$, probably because it was in the transition between the states since the CD spectrum is the median of the sample's secondary structure. After two days of incubation, the sample with QF2D-1 showed a maximum at $205 \mathrm{~nm}$, similar to ARQ46 alone, which had a maximum at $201 \mathrm{~nm}$. This could be due to slightly different betasheet structures. It seems as if QF2D-1 decelerated ARQ46's misfolding. The maximum at $205 \mathrm{~nm}$ is approx. 25\% smaller than for ARQ46 alone, but after two days the transition seems to be complete as well.

This was not the case for the sample containing QF2D-2 and ARQ46 (Figure 6C,D). After $24 \mathrm{~h}$ incubation at $37^{\circ} \mathrm{C}$ it still had a minimum at $205 \mathrm{~nm}$ although the minima's amplitude was reduced compared to the spectrum of the freshly disaggregated sample. The transition to beta-sheet structures did not seem to have progressed as in the other samples at this time point. After $48 \mathrm{~h}$ at $37^{\circ} \mathrm{C}$ this sample had a positive peak at $205 \mathrm{~nm}$ as well, but it was $90 \%$ smaller than that of ARQ46 alone, making it plausible that the sample is still partly in random coil conformation. Seven days after the disaggregation, the sample with QF2D-2 was refolded to beta-sheet as well. As observed for QF2D-1 the maximum was smaller than that of ARQ46 alone. Consistent with the aggregation study results, QF2D-2 seems to delay the transition to beta-sheet structures.

Summarizing the results so far, QF2D-2 seems to be the most promising candidate. Thus, its effect on ARQ46 aggregation was also tested when soluble and insoluble aggregates served as seeds. Here, the inhibiting effect of QF2D-2 was even stronger than the one on solely soluble aggregate seeded aggregation (Figure 7). The stronger effect might be due to large, insoluble fibrils that make up the majority of the seeds and partly precipitate out of the solution and therefore have a lower seeding capability than soluble aggregates [49]. Smaller aggregates might also have larger surfaces that can interact with the monomers. Furthermore, smaller fibril fragments will also present more ends for elongation than fewer, longer fibrils. 
A
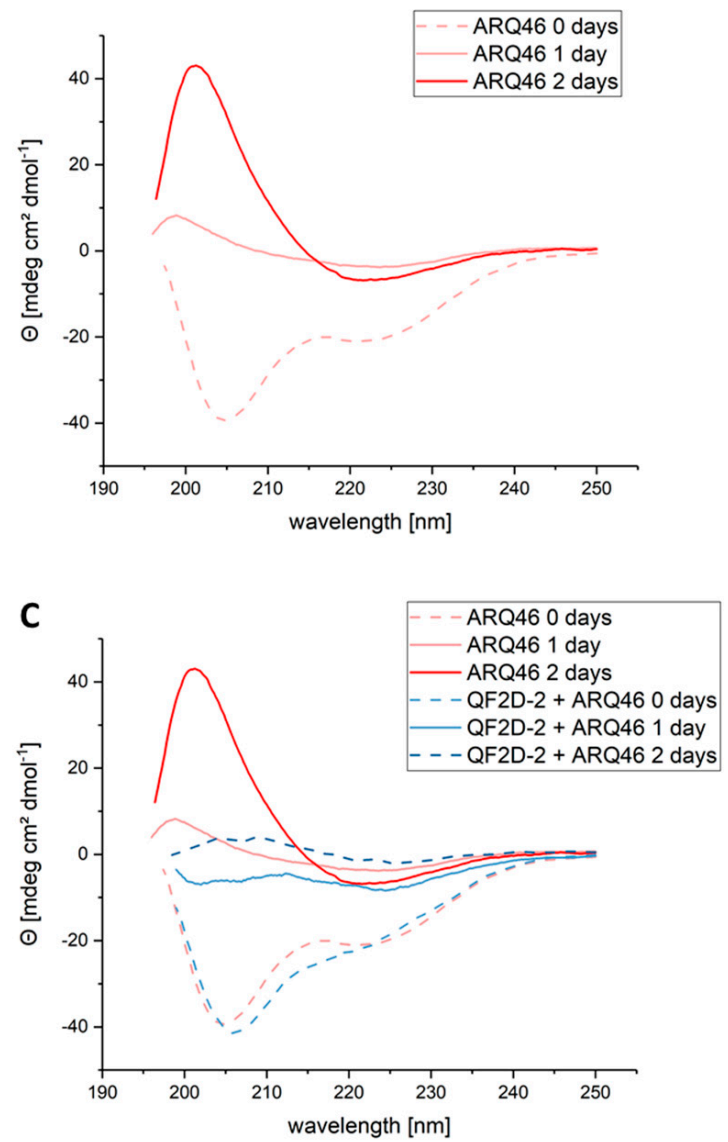

B
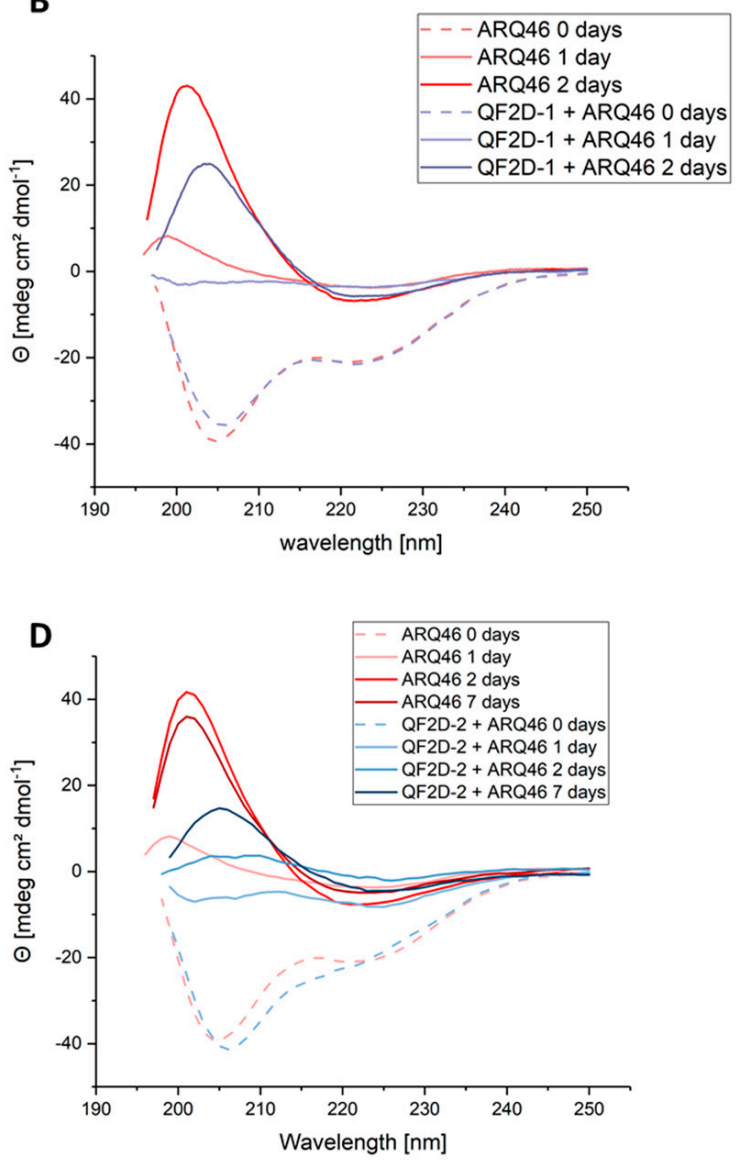

Figure 6. Investigation of structural change of ARQ46 in presence of QF2D-1 or QF2D-2 with CD spectroscopy; ARQ46 was disaggregated with 1:1 TFA/HFIP and diluted to $50 \mu \mathrm{M}$ in TBS pH 7.5. $50 \mu \mathrm{M}$ QF2D-1 or QF2D-2 were added to one sample. As a control and reference, $50 \mu \mathrm{M}$ QF2D-1 or QF2D-2 alone were measured. (A) Spectra measured directly after disaggregation for $50 \mu \mathrm{M}$ ARQ46 (rose, dashed)- referenced with buffer; $50 \mu \mathrm{M}$ ARQ46 after $24 \mathrm{~h}$ incubation at $37^{\circ} \mathrm{C}$ (rose, straight) and $50 \mu \mathrm{M}$ ARQ46 after $48 \mathrm{~h}$ incubation at $37^{\circ} \mathrm{C}$ (red, straight) (B) Spectra measured directly after disaggregation for $50 \mu \mathrm{M}$ ARQ46 (rose, dashed)- referenced with buffer; equimolar ARQ46 and QF2D-1 (light purple, dashed)- referenced with QF2D-1 in TBS; $50 \mu \mathrm{M}$ ARQ46 after $24 \mathrm{~h}$ incubation at $37^{\circ} \mathrm{C}$ (rose, straight) and equimolar ARQ46 and QF2D-1 (light purple, straight)- referenced with QF2D-1 in TBS and $50 \mu \mathrm{M}$ ARQ46 after $48 \mathrm{~h}$ incubation at $37^{\circ} \mathrm{C}$ (red, straight) and equimolar ARQ46 and QF2D-1 (purple, straight)- referenced with QF2D-1 in TBS (C) Spectra measured directly after disaggregation for $50 \mu \mathrm{M}$ ARQ46 (rose, dashed)- referenced with buffer and equimolar ARQ46 and QF2D-2 (light blue, dashed)- referenced with QF2D-2 in TBS; $50 \mu \mathrm{M}$ ARQ46 after $24 \mathrm{~h}$ incubation at $37^{\circ} \mathrm{C}$ (rose, straight) and equimolar ARQ46 and QF2D-2 (light blue, straight)- referenced with QF2D-2 in TBS and $50 \mu \mathrm{M}$ ARQ46 after $48 \mathrm{~h}$ incubation at $37^{\circ} \mathrm{C}$ (red, straight) and equimolar ARQ46 and QF2D-2 (light blue, straight)- referenced with QF2D-2 in TBS (D) Spectra measured directly after disaggregation for $50 \mu \mathrm{M}$ ARQ46 (rose, dashed)- referenced with buffer; equimolar ARQ46 and QF2D-2 (light blue, dashed)- referenced with QF2D-2 in TBS; $50 \mu \mathrm{M}$ ARQ46 after $24 \mathrm{~h}$ incubation at $37^{\circ} \mathrm{C}$ (rose, straight) and equimolar ARQ46 and QF2D-2 (light blue, straight)- referenced with QF2D-2 in TBS; $50 \mu \mathrm{M}$ ARQ46 after $48 \mathrm{~h}$ incubation at $37^{\circ} \mathrm{C}$ (red) and equimolar ARQ46 and QF2D-2 (blue)- referenced with QF2D-2 in TBS; $50 \mu \mathrm{M}$ ARQ46 after $168 \mathrm{~h}$ incubation at $37^{\circ} \mathrm{C}$ (dark red) and equimolar ARQ46 and QF2D-2 (dark blue)- referenced with QF2D-2 in TBS. 
A

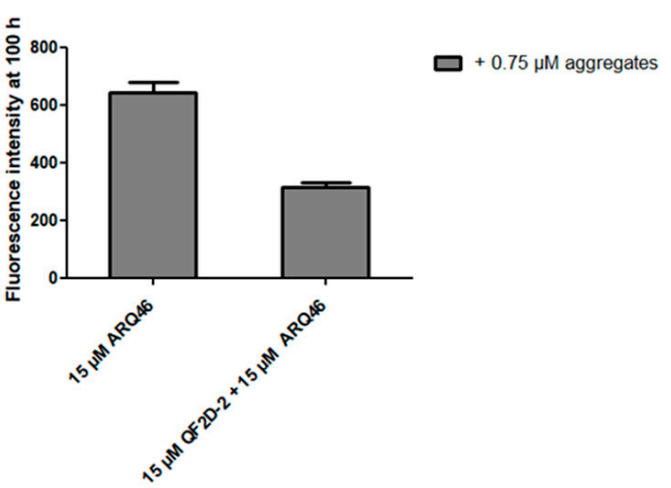

B

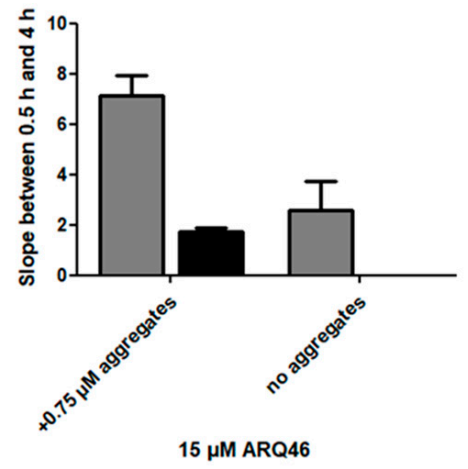

0 MM QF2D-2

$15 \mu \mathrm{M}$ QF2D-2

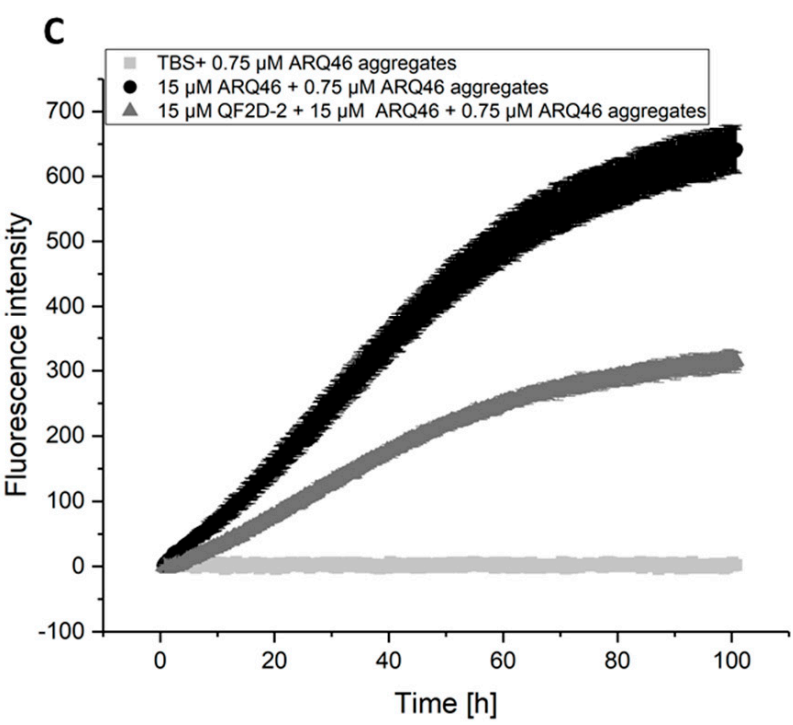

Figure 7. QF2D-2 inhibits the aggregation of ARQ46 in presence of soluble and insoluble seeds; ThT assay with L-ARQ46 was performed at $37{ }^{\circ} \mathrm{C}$ in TBS $\mathrm{pH}$ 7.5. Pre-formed ARQ46 aggregates were added in an amount of $5 \%$ monomer equivalent. The progression of fluorescence intensity was measured every $8 \mathrm{~min}$ at $\lambda \mathrm{ex}=448 \mathrm{~nm}$ and $\lambda \mathrm{em}=482 \mathrm{~nm}$ with agitation at $300 \mathrm{rpm}$ between measurements. (A) Fluorescence intensity measured at $100 \mathrm{~h}$ of the aggregation assay starting with $15 \mu \mathrm{M}$ monomeric ARQ46, $0.75 \mu \mathrm{M}$ soluble and insoluble ARQ46 aggregates and $15 \mu \mathrm{M}$ QF2D-2. (B) The data points acquired between $0.5 \mathrm{~h}$ and $4 \mathrm{~h}$ were fitted with a linear fit. The slope was compared with the one measured for ARQ46 aggregation without seeds. (C) Measurement of ThT-fluorescence intensity with $15 \mu \mathrm{M}$ ARQ46 (black) and $15 \mu \mathrm{M}$ QF2D-2 (dark grey). $15 \mu \mathrm{M}$ QF2D-2 with $0.75 \mu \mathrm{M}$ ARQ46 aggregates served as control. The mean fluorescence intensity is shown for each time point. The experiment was performed in three-fold determination.

The aggregation experiment with monomeric ARQ46 was repeated with control compounds P8, which had a slight inhibiting effect on the aggregation when present in equimolar concentration, but the aggregation was similar to that of ARQ46 alone when P8 was present in a sub stoichiometric relation. When the aggregation experiment began with monomeric ARQ46, QBP1 drastically inhibited the aggregation, differing from the results of the seeded assay (Figure 5). QF2D-2 had an inhibiting effect, even when ARQ46 was in excess but in contrast to the seeded assay with soluble aggregate fragments the effect was not as strong as QBP1's effect. QF2D-2 lowered the fluorescence intensity of the steady state and elongated the lag time compared to ARQ46 alone and with P8 (data not shown).

As described before, QF2D-2 inhibits aggregation when the polyglutamine protein is present in excess. This was verified in another aggregation experiment, showing that 
QF2D-2 had an inhibiting effect in a 1:3 ratio (QF2D-1:ARQ46). The effect was concentration dependend (Figure 8).

A

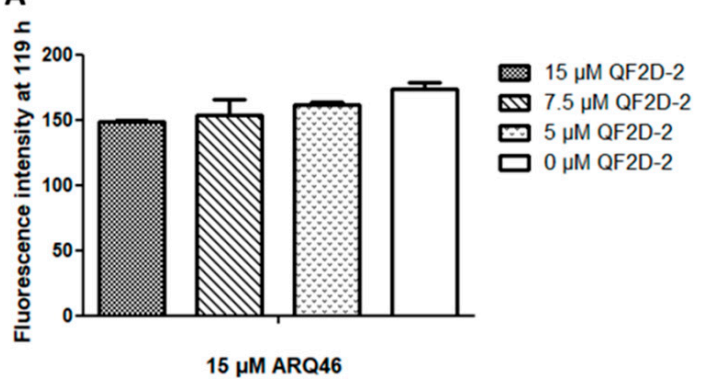

B

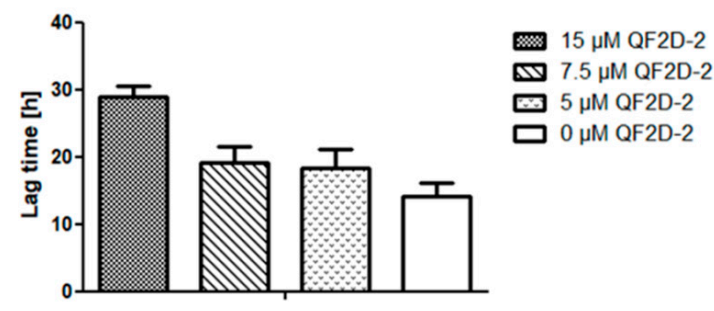

$15 \mu M$ ARQ46

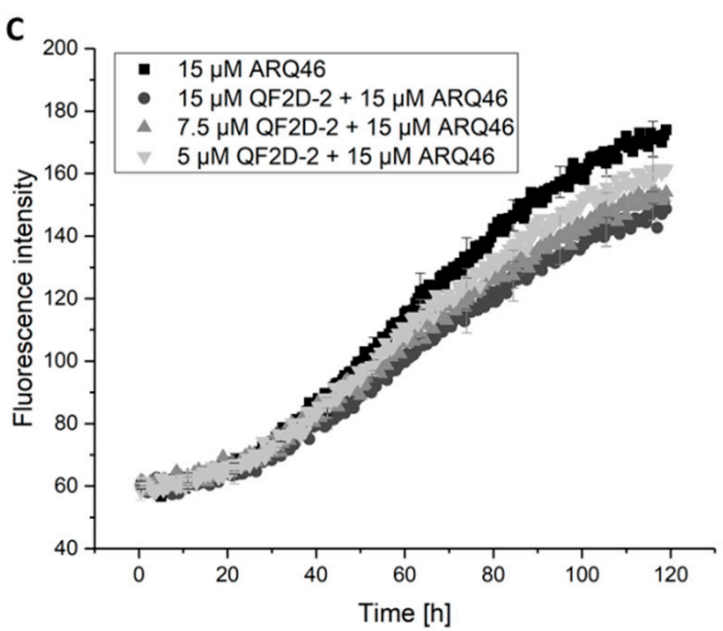

Figure 8. Effect of different QF2D-2 concentrations on the aggregation of ARQ46; ThT assay with L-ARQ46 was performed at $37{ }^{\circ} \mathrm{C}$ in TBS $\mathrm{pH}$ 7.5. The progression of fluorescence intensity was measured every $30 \mathrm{~min}$ at $\lambda \mathrm{ex}=410 \mathrm{~nm}$ and $\lambda \mathrm{em}=482 \mathrm{~nm}$ with $30 \mathrm{sec}$ agitation at $300 \mathrm{rpm}$ before every measurement. (A) Fluorescence intensity measured at $119 \mathrm{~h}$ of the aggregation assay starting with $15 \mu \mathrm{M}$ monomeric ARQ46 and $15 \mu \mathrm{M}$ QF2D-2, $7.5 \mu \mathrm{M}$ QF2D-2 or $5 \mu \mathrm{M}$ QF2D-2. (B) Lag time estimated from the aggregation assay of $15 \mu \mathrm{M}$ monomeric ARQ46 and $15 \mu \mathrm{M}$ QF2D-2, $7.5 \mu \mathrm{M}$ QF2D2 or $5 \mu \mathrm{M}$ QF2D-2. (C) Measurement example of the described ThT-assay with $15 \mu \mathrm{M}$ ARQ46 (black), $15 \mu \mathrm{M}$ QF2D-2 (dark grey), $7.5 \mu \mathrm{M}$ (grey) and $5 \mu \mathrm{M}$ QF2D-2 (light grey). The mean fluorescence intensity is shown for each time point. The experiment was performed in three-fold determination.

\subsection{Binding to Polyglutamine Proteins}

The binding properties of QF2D-2 to L-polyglutamine proteins were investigated by SPR. The QF2D-2 showed detectable binding to L-ARQ46. It bound with a $\mathrm{K}_{\mathrm{D}}$ of $11 \mu \mathrm{M}$ when L-ARQ46 was immobilized on the chip (data not shown).

This study aimed to identify ligands for polyglutamine-containing proteins. In order to investigate whether QF2D-2's effect is constrained to the androgen receptor fragment used in the study, further SPR experiments were performed to investigate QF2D-2's binding to more general polyglutamine constructs (L-K2Q23K2 and K2Q46K2). The glutamine flanking lysines were introduced to increase solubility in aqueous buffers [40].

Indeed, QF2D-2 bound to the general polyglutamine construct K2Q46K2 and inhibited its aggregation. It lowered the fluorescence intensity of the steady state and elongated the lag time compared to the effect of P8 (Figure 9). Thus, it may be feasible to transfer the compound's inhibitory effect on aggregation to other polyglutamine containing proteins. 
A

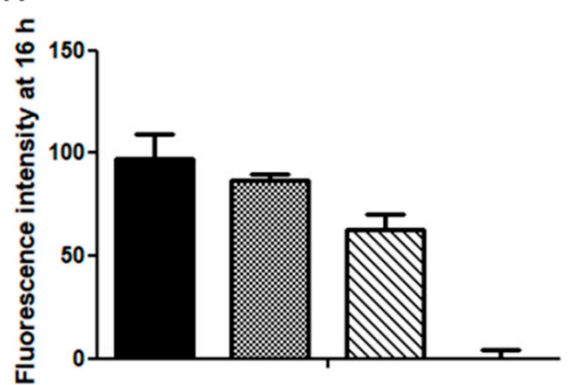

$30 \mu \mathrm{M} \mathrm{K2Q46K2}$
B

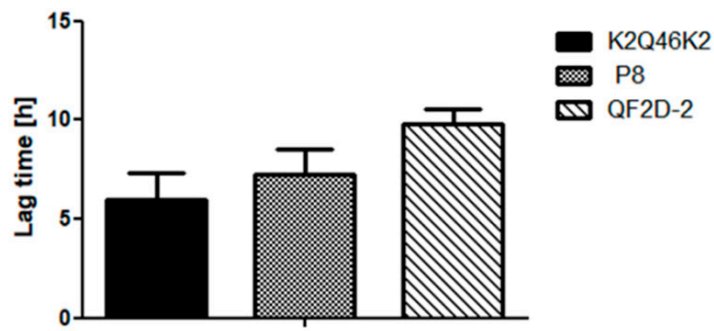

$30 \mu \mathrm{M}$ K2Q46K2

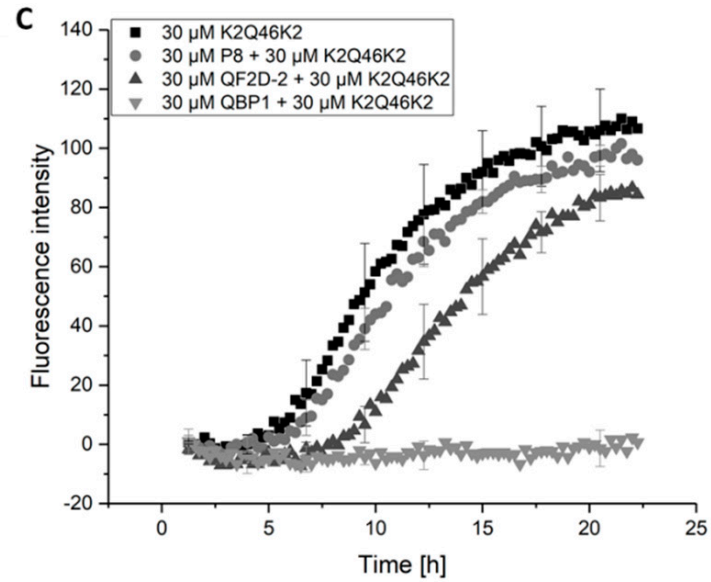

Figure 9. QF2D-2 inhibits the aggregation of K2Q46K2; ThT assay with L-K2Q46K2 was performed at $37{ }^{\circ} \mathrm{C}$ in TBS $\mathrm{pH}$ 7.5. The progression of fluorescence intensity was measured every $15 \mathrm{~min}$ at $\lambda \mathrm{ex}=450 \mathrm{~nm}$ and $\lambda \mathrm{em}=480 \mathrm{~nm}$ with $300 \mathrm{~s}$ agitation at $300 \mathrm{rpm}$ before every measurement. (A) Fluorescence intensity measured at $16 \mathrm{~h}$ of the aggregation assay starting with $30 \mu \mathrm{M}$ monomeric K2Q46K2 and $30 \mu \mathrm{M}$ QF2D-2, P8 or QBP1. (B) Lag times estimated from the aggregation assay of $30 \mu \mathrm{M}$ monomeric K2Q46K2 and $30 \mu \mathrm{M}$ QF2D-2 or P8. (C) Measurement example of described ThT-assay with K2Q46K2 (black) and QF2D-2 (dark grey) as well as P8 (grey) or QBP1 (light grey). The experiment was performed in three-fold determination.

\section{Discussion}

The development of suitable therapeutics for SBMA is urgent, since no causative therapy is known. Instead of inhibiting or reducing the expression of the respective gene coding for the polyglutamine containing proteins [50-52], we aim to stabilize the protein's native conformation by D-enantiomeric peptide ligands to prevent misfolding and aggregation, shift the equilibrium between aggregates and monomers towards monomers and dissolve the already existing aggregates into non-toxic and functional monomers. To this end a mirror image phage display selection was performed on a fragment of the androgen receptor, in which an elongated polyglutamine tract causes SBMA.

As is known, QBP1 is an L-enantiomeric peptide, which was selected on polyglutamine that had a therapeutic effect in Drosophila [34], but did not yield beneficial neurological effects in a respective mouse model [53-55].

L-enantiomeric peptide compounds metabolize rather quickly. Thus, we develop D-enantiomeric peptide ligands of polyglutamine proteins, a principle that was already shown to be effective in other neurodegenerative diseases [39]. D-enantiomeric peptides are, metabolically, considerably more stable [35], thus regular administration can lead to higher concentrations in the tissue. 


\section{Conclusions}

An unphysiologically elongated polyglutamine tract causes protein misfolding and aggregation, leading to neurodegeneration. We performed a mirror image phage display selection on an all D-enantiomeric polyglutamine target to identify all D-enantiomeric peptide ligands for L-enantiomeric polyglutamine proteins. During the subsequent characterization of the all D-enantiomeric peptide compounds, we identified QF2D-2 to be the most promising among the nine compounds tested. Furthermore, QF2D-2 delayed the ThT-active aggregation of ARQ46, even under seeding conditions. CD spectroscopy measurements showed that QF2D-2 stabilizes ARQ46 in its native conformation and delays the transition to beta-sheet rich structures. Additionally, QF2D-2 not only bound to ARQ46 and inhibited its ThT-active aggregation, but also the more general target K2Q46K2, suggesting that it may be used and further developed as a more general compound, targeting and stabilizing polyglutamine containing proteins.

Author Contributions: Conceptualization, D.W.; methodology, D.W.; validation, P.E.K.; formal analysis, P.E.K.; investigation, P.E.K.; writing-original draft preparation, P.E.K.; writing-review and editing, J.M. and D.W.; visualization, P.E.K.; supervision, J.M. and D.W.; project administration, J.M. and D.W.; funding acquisition, D.W. All authors have read and agreed to the published version of the manuscript.

Funding: This research received no external funding.

Institutional Review Board Statement: Not applicable.

Informed Consent Statement: Not applicable.

Acknowledgments: We would like to thank the Biologisch Medizinisches Forschungszentrum of the Heinrich Heine University Düsseldorf for performing the NGS analysis.

Conflicts of Interest: The authors declare no conflict of interest.

\section{References}

1. Pastore, A.; Temussi, P.A. The two faces of Janus: Functional interactions and protein aggregation. Curr. Opin. Struct. Biol. 2012, 22, 30-37. [CrossRef]

2. Lapidus, L.J. Understanding protein aggregation from the view of monomer dynamics. Mol. BioSyst. 2013, 9, 29-35. [CrossRef]

3. Adegbuyiro, A.; Sedighi, F.; Pilkington, A.W.t.; Groover, S.; Legleiter, J. Proteins Containing Expanded Polyglutamine Tracts and Neurodegenerative Disease. Biochemistry 2017, 56, 1199-1217. [CrossRef] [PubMed]

4. $\quad$ Gremer, L.; Schölzel, D.; Schenk, C.; Reinartz, E.; Labahn, J.; Ravelli, R.B.; Tusche, M.; Lopez-Iglesias, C.; Hoyer, W.; Heise, H.; et al. Fibril structure of amyloid- $\beta$ (1-42) by cryo-electron microscopy. Science 2017, 358, 116-119. [CrossRef] [PubMed]

5. $\quad$ Roder, C.; Vettore, N.; Mangels, L.N.; Gremer, L.; Ravelli, R.B.G.; Willbold, D.; Hoyer, W.; Buell, A.K.; Schroder, G.F. Atomic structure of PI3-kinase SH3 amyloid fibrils by cryo-electron microscopy. Nat. Commun. 2019, 10, 3754. [CrossRef] [PubMed]

6. Rothlein, C.; Miettinen, M.S.; Borwankar, T.; Burger, J.; Mielke, T.; Kumke, M.U.; Ignatova, Z. Architecture of polyglutaminecontaining fibrils from time-resolved fluorescence decay. J. Biol. Chem. 2014, 289, 26817-26828. [CrossRef]

7. Willbold, D.; Strodel, B.; Schroder, G.F.; Hoyer, W.; Heise, H. Amyloid-type Protein Aggregation and Prion-like Properties of Amyloids. Chem. Rev. 2021, 121, 8285-8307. [CrossRef]

8. Hartl, F.U. Protein Misfolding Diseases. Annu. Rev. Biochem. 2017, 86, 21-26. [CrossRef]

9. Spillantini, M.G.; Bird, T.D.; Ghetti, B. Frontotemporal dementia and Parkinsonism linked to chromosome 17: A new group of tauopathies. Brain Pathol. 1998, 8, 387-402. [CrossRef]

10. Hardy, J.; Selkoe, D.J. The amyloid hypothesis of Alzheimer's disease: Progress and problems on the road to therapeutics. Science 2002, 297, 353-356. [CrossRef]

11. Nordlund, A.; Oliveberg, M. SOD1-associated ALS: A promising system for elucidating the origin of protein-misfolding disease. HFSP J. 2008, 2, 354-364. [CrossRef]

12. Schaefer, M.H.; Wanker, E.E.; Andrade-Navarro, M.A. Evolution and function of CAG/polyglutamine repeats in protein-protein interaction networks. Nucleic Acids Res. 2012, 40, 4273-4287. [CrossRef]

13. Butland, S.L.; Devon, R.S.; Huang, Y.; Mead, C.L.; Meynert, A.M.; Neal, S.J.; Lee, S.S.; Wilkinson, A.; Yang, G.S.; Yuen, M.M.; et al. CAG-encoded polyglutamine length polymorphism in the human genome. BMC Genom. 2007, 8, 126. [CrossRef]

14. Chen, S.; Ferrone, F.A.; Wetzel, R. Huntington's disease age-of-onset linked to polyglutamine aggregation nucleation. Proc. Natl. Acad. Sci. USA 2002, 99, 11884-11889. [CrossRef]

15. Kar, K.; Jayaraman, M.; Sahoo, B.; Kodali, R.; Wetzel, R. Critical nucleus size for disease-related polyglutamine aggregation is repeat-length dependent. Nat. Struct. Mol. Biol. 2011, 18, 328-336. [CrossRef] 
16. Landrum, E.; Wetzel, R. Biophysical underpinnings of the repeat length dependence of polyglutamine amyloid formation. J. Biol. Chem. 2014, 289, 10254-10260. [CrossRef] [PubMed]

17. Trevino, R.S.; Lauckner, J.E.; Sourigues, Y.; Pearce, M.M.; Bousset, L.; Melki, R.; Kopito, R.R. Fibrillar structure and charge determine the interaction of polyglutamine protein aggregates with the cell surface. J. Biol. Chem. 2012, 287, 29722-29728. [CrossRef]

18. Chen, S.; Berthelier, V.; Yang, W.; Wetzel, R. Polyglutamine aggregation behavior in vitro supports a recruitment mechanism of cytotoxicity. J. Mol. Biol. 2001, 311, 173-182. [CrossRef]

19. Takeuchi, T.; Nagai, Y. Protein Misfolding and Aggregation as a Therapeutic Target for Polyglutamine Diseases. Brain Sci. 2017, 7 , 128. [CrossRef] [PubMed]

20. MacDonald, M.; Ambrose, C.; Duyao, M.; Myers, R.; Lin, C.; Srinidhi, L.; Barnes, G.; Taylor, S.; James, M.; Groot, N. The Huntington's Disease Collaborative Research Group. A novel gene containing a trinucleotide repeat that is expanded and unstable on Huntington's disease chromosomes. Cell 1993, 72, 971-983. [CrossRef]

21. La Spada, A.R.; Wilson, E.M.; Lubahn, D.B.; Harding, A.; Fischbeck, K.H. Androgen receptor gene mutations in X-linked spinal and bulbar muscular atrophy. Nature 1991, 352, 77-79. [CrossRef]

22. Orr, H.T.; Chung, M.-y.; Banfi, S.; Kwiatkowski, T.J.; Servadio, A.; Beaudet, A.L.; McCall, A.E.; Duvick, L.A.; Ranum, L.P.; Zoghbi, H.Y. Expansion of an unstable trinucleotide CAG repeat in spinocerebellar ataxia type 1. Nat. Genet. 1993, 4, 221-226. [CrossRef] [PubMed]

23. Pulst, S.M.; Santos, N.; Wang, D.; Yang, H.; Huynh, D.; Velazquez, L.; Figueroa, K.P. Spinocerebellar ataxia type 2: PolyQ repeat variation in the CACNA1A calcium channel modifies age of onset. Brain 2005, 128, 2297-2303. [CrossRef] [PubMed]

24. Kawaguchi, Y.; Okamoto, T.; Taniwaki, M.; Aizawa, M.; Inoue, M.; Katayama, S.; Kawakami, H.; Nakamura, S.; Nishimura, M.; Akiguchi, I. CAG expansions in a novel gene for Machado-Joseph disease at chromosome 14q32. 1. Nat. Genet. 1994, 8, 221-228. [CrossRef] [PubMed]

25. Zhuchenko, O.; Bailey, J.; Bonnen, P.; Ashizawa, T.; Stockton, D.W.; Amos, C.; Dobyns, W.B.; Subramony, S.; Zoghbi, H.Y.; Lee, C.C. Autosomal dominant cerebellar ataxia (SCA6) associated with small polyglutamine expansions in the $\alpha 1 \mathrm{~A}$-voltage-dependent calcium channel. Nat. Genet. 1997, 15, 62-69. [CrossRef]

26. Benton, C.; De Silva, R.; Rutledge, S.; Bohlega, S.; Ashizawa, T.; Zoghbi, H. Molecular and clinical studies in SCA-7 define a broad clinical spectrum and the infantile phenotype. Neurology 1998, 51, 1081-1086. [CrossRef]

27. David, G.; Abbas, N.; Stevanin, G.; Dürr, A.; Yvert, G.; Cancel, G.; Weber, C.; Imbert, G.; Saudou, F.; Antoniou, E. Cloning of the SCA7 gene reveals a highly unstable CAG repeat expansion. Nat. Genet. 1997, 17, 65-70. [CrossRef] [PubMed]

28. Nakamura, K.; Jeong, S.-Y.; Uchihara, T.; Anno, M.; Nagashima, K.; Nagashima, T.; Ikeda, S.-i.; Tsuji, S.; Kanazawa, I. SCA17, a novel autosomal dominant cerebellar ataxia caused by an expanded polyglutamine in TATA-binding protein. Hum. Mol. Genet. 2001, 10, 1441-1448. [CrossRef]

29. Ueno, S.-I.; Kondoh, K.; Komure, Y.; Komure, O.; Kuno, S.; Kawai, J.; Hazama, F.; Sano, A. Somatic mosaicism of CAG repeat in dentatorubral-pallidoluysian atrophy (DRPLA). Hum. Mol. Genet. 1995, 4, 663-666. [CrossRef]

30. Gutekunst, C.-A.; Li, S.-H.; Yi, H.; Mulroy, J.S.; Kuemmerle, S.; Jones, R.; Rye, D.; Ferrante, R.J.; Hersch, S.M.; Li, X.-J. Nuclear and neuropil aggregates in Huntington's disease: Relationship to neuropathology. J. Neurosci. 1999, 19, 2522-2534. [CrossRef]

31. Kuemmerle, S.; Gutekunst, C.A.; Klein, A.M.; Li, X.J.; Li, S.H.; Beal, M.F.; Hersch, S.M.; Ferrante, R.J. Huntingtin aggregates may not predict neuronal death in Huntington's disease. Ann. Neurol. 1999, 46, 842-849. [CrossRef]

32. Huynh, D.P.; Figueroa, K.; Hoang, N.; Pulst, S.-M. Nuclear localization or inclusion body formation of ataxin-2 are not necessary for SCA2 pathogenesis in mouse or human. Nat. Genet. 2000, 26, 44. [CrossRef]

33. Nagai, Y.; Tucker, T.; Ren, H.; Kenan, D.J.; Henderson, B.S.; Keene, J.D.; Strittmatter, W.J.; Burke, J.R. Inhibition of polyglutamine protein aggregation and cell death by novel peptides identified by phage display screening. J. Biol. Chem. 2000, 275, 10437-10442. [CrossRef] [PubMed]

34. Nagai, Y.; Fujikake, N.; Ohno, K.; Higashiyama, H.; Popiel, H.A.; Rahadian, J.; Yamaguchi, M.; Strittmatter, W.J.; Burke, J.R.; Toda, T. Prevention of polyglutamine oligomerization and neurodegeneration by the peptide inhibitor QBP1 in Drosophila. Hum. Mol. Genet. 2003, 12, 1253-1259. [CrossRef] [PubMed]

35. Schumacher, T.N.; Mayr, L.M.; Minor, D.L.; Milhollen, M.A.; Burgess, M.W.; Kim, P.S. Identification of D-peptide ligands through mirror-image phage display. Science 1996, 271, 1854-1857. [CrossRef] [PubMed]

36. Elfgen, A.; Santiago-Schübel, B.; Gremer, L.; Kutzsche, J.; Willbold, D. Surprisingly high stability of the A $\beta$ oligomer eliminating all-d-enantiomeric peptide D3 in media simulating the route of orally administered drugs. Eur. J. Pharm. Sci. 2017, 107, 203-207. [CrossRef] [PubMed]

37. Wiesehan, K.; Willbold, D. Mirror-image phage display: Aiming at the mirror. ChemBioChem 2003, 4, 811-815. [CrossRef]

38. Funke, S.A.; Willbold, D. Mirror image phage display-A method to generate D-peptide ligands for use in diagnostic or therapeutical applications. Mol. BioSyst. 2009, 5, 783-786. [CrossRef]

39. Van Groen, T.; Schemmert, S.; Brener, O.; Gremer, L.; Ziehm, T.; Tusche, M.; Nagel-Steger, L.; Kadish, I.; Schartmann, E.; Elfgen, A.; et al. The Abeta oligomer eliminating D-enantiomeric peptide RD2 improves cognition without changing plaque pathology. Sci. Rep. 2017, 7, 16275. [CrossRef]

40. Chen, S.; Wetzel, R. Solubilization and disaggregation of polyglutamine peptides. Protein Sci. 2001, 10, 887-891. [CrossRef] 
41. Casadevall, A.; Day, L.A. DNA packing in the filamentous viruses fd, Xf, Pfl and Pf3. Nucleic Acids Res. 1982, 10, $2467-2481$. [CrossRef] [PubMed]

42. Santur, K.; Reinartz, E.; Lien, Y.; Tusche, M.; Altendorf, T.; Sevenich, M.; Tamguney, G.; Mohrluder, J.; Willbold, D. Ligand-Induced Stabilization of the Native Human Superoxide Dismutase 1. ACS Chem. Neurosci. 2021, 12, 2520-2528. [CrossRef]

43. Krejci, A.; Hupp, T.R.; Lexa, M.; Vojtesek, B.; Muller, P. Hammock: A hidden Markov model-based peptide clustering algorithm to identify protein-interaction consensus motifs in large datasets. Bioinformatics 2016, 32, 9-16. [CrossRef]

44. Bhattacharyya, A.; Thakur, A.K.; Chellgren, V.M.; Thiagarajan, G.; Williams, A.D.; Chellgren, B.W.; Creamer, T.P.; Wetzel, R. Oligoproline effects on polyglutamine conformation and aggregation. J. Mol. Biol. 2006, 355, 524-535. [CrossRef] [PubMed]

45. Futaki, S.; Goto, S.; Sugiura, Y. Membrane permeability commonly shared among arginine-rich peptides. J. Mol. Recognit. 2003, 16, 260-264. [CrossRef]

46. Kim, Y.E.; Hosp, F.; Frottin, F.; Ge, H.; Mann, M.; Hayer-Hartl, M.; Hartl, F.U. Soluble Oligomers of PolyQ-Expanded Huntingtin Target a Multiplicity of Key Cellular Factors. Mol. Cell 2016, 63, 951-964. [CrossRef]

47. Terzi, E.; Hoelzemann, G.; Seelig, J. Reversible Random Coil-. beta.-Sheet Transition of the Alzheimer. beta.-Amyloid Fragment. Biochemistry 1994, 33, 1345-1350. [CrossRef]

48. Kar, K.; Hoop, C.L.; Drombosky, K.W.; Baker, M.A.; Kodali, R.; Arduini, I.; van der Wel, P.C.; Horne, W.S.; Wetzel, R. beta-hairpinmediated nucleation of polyglutamine amyloid formation. J. Mol. Biol. 2013, 425, 1183-1197. [CrossRef]

49. Lam, H.T.; Graber, M.C.; Gentry, K.A.; Bieschke, J. Stabilization of alpha-Synuclein Fibril Clusters Prevents Fragmentation and Reduces Seeding Activity and Toxicity. Biochemistry 2016, 55, 675-685. [CrossRef] [PubMed]

50. Lim, W.F.; Forouhan, M.; Roberts, T.C.; Dabney, J.; Ellerington, R.; Speciale, A.A.; Manzano, R.; Lieto, M.; Sangha, G.; Banerjee, S.; et al. Gene therapy with AR isoform 2 rescues spinal and bulbar muscular atrophy phenotype by modulating AR transcriptional activity. Sci. Adv. 2021, 7, eabi6896. [CrossRef]

51. Lieberman, A.P.; Yu, Z.; Murray, S.; Peralta, R.; Low, A.; Guo, S.; Yu, X.X.; Cortes, C.J.; Bennett, C.F.; Monia, B.P. Peripheral androgen receptor gene suppression rescues disease in mouse models of spinal and bulbar muscular atrophy. Cell Rep. 2014, 7, 774-784. [CrossRef]

52. Sahashi, K.; Katsuno, M.; Hung, G.; Adachi, H.; Kondo, N.; Nakatsuji, H.; Tohnai, G.; Iida, M.; Bennett, C.F.; Sobue, G. Silencing neuronal mutant androgen receptor in a mouse model of spinal and bulbar muscular atrophy. Hum. Mol. Genet. 2015, 24, 5985-5994. [CrossRef] [PubMed]

53. Popiel, H.A.; Nagai, Y.; Fujikake, N.; Toda, T. Delivery of the aggregate inhibitor peptide QBP1 into the mouse brain using PTDs and its therapeutic effect on polyglutamine disease mice. Neurosci. Lett. 2009, 449, 87-92. [CrossRef] [PubMed]

54. Popiel, H.A.; Takeuchi, T.; Fujita, H.; Yamamoto, K.; Ito, C.; Yamane, H.; Muramatsu, S.; Toda, T.; Wada, K.; Nagai, Y. Hsp40 gene therapy exerts therapeutic effects on polyglutamine disease mice via a non-cell autonomous mechanism. PLoS ONE 2012, 7 , e51069. [CrossRef] [PubMed]

55. Popiel, H.A.; Takeuchi, T.; Burke, J.R.; Strittmatter, W.J.; Toda, T.; Wada, K.; Nagai, Y. Inhibition of protein misfolding/aggregation using polyglutamine binding peptide QBP1 as a therapy for the polyglutamine diseases. Neurotherapeutics 2013, 10, 440-446. [CrossRef] [PubMed] 